\title{
Analyses of the Tourism Potentials of Dala Hill, Kano Metropolis: Protecting Heritage Properties and Promoting Sustainable Tourism
}

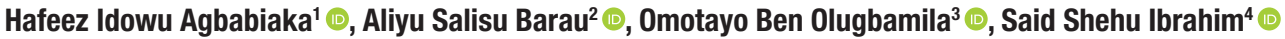

\begin{abstract}
The relationship between human and the Built environments in its complex nature evolved series of consequences as loss of heritage properties through decay, natural hazard, human factors in the modern society. Hence, this study analyzed the heritage tourism potentials of Dala Hill, Kano Metropolis, Nigeria. Both qualitative and quantitative data was collected through detailed inventory and profiling of the site and questionnaire administration on two categories of respondents (above 60years (Aged) and Between 18 - 59years (Agile)) within 300meters vicinity to the site. Therefore, 45 (Aged) people were selected using snowballing sampling procedure, and 262 (Agile) respondents were surveyed using systematic sampling procedure. Findings revealed that Dala hill is faced with the threats of neglect, decay and deterioration induced through weathering and human activities. It has poor sanitary conditions, open defecation, waste disposal, poor accessibility, and is an abode for hoodlums. However, resident perceived the site to generate more economic (RPI = 3.38) and sociocultural (RPI = 3.27) importance, and moderate environmental (RPI = 3.18) importance in the study area if necessary, attention, restoration and transformation plan are designed and implemented.
\end{abstract}

Keywords

Dala Hill, Heritage Properties, Tourism Potentials, Tourism Sustainability, SDGs, and Conservation

1 Correspondence to: Hafeez Idowu Agbabiaka, Bayero University, Faculty of Earth and Environmental Sciences, Department of Urban and Regional Planning, Kano, Nigeria. E-mail: wisdomislifee@yahoo.com ORCID: 0000-0003-4872-7105

2 Aliyu Salisu Barau (Assoc. Prof), Bayero University, Faculty of Earth and Environmental Sciences, Department of Urban and Regional Planning, Kano, Nigeria. E-mail: asbarau.urp@buk.edu.ng ORCID: 0000-0002-1259-3929

3 Omotayo Ben Olugbamila, Obafemi Awolowo University, Faculty of Environmental Design and Management, Department of Urban and Regional Planning, Ile-Ife, Nigeria. E-mail: benmotayo@yahoo.com ORCID: 0000-0001-5641-9917

4 Said Shehu Ibrahim, Bayero University, Faculty of Earth and Environmental Sciences, Department of Urban and Regional Planning, Kano, Nigeria. E-mail: kalipasaid@gmail.com ORCID: 0000-0001-5219-014X

To cite this article: Agbabiaka, H. I., Barau, A. S., Olugbamila, O. B., \& Ibrahim, S. S. (2021). Analyses of the Tourism Potentials of Dala Hill, Kano Metropolis: Protecting Heritage Properties and Promoting Sustainable Tourism. Journal of Tourismology, 7(2), $227-239$. https://doi.org/10.26650/jot.2021.7.2.1000584 


\section{Introduction}

Protecting cultural and natural heritage has significant impact on the quality of life of the people as well as enhancing the economic situation of the environment (Di-Pietro, Guglielmetti, Mattia, and Renzi, 2015). Cultural heritage is a valuable and irreplaceable body of knowledge and resources that promote economic growth, employment, and social cohesion (Vecco, 2010). The loss of heritage properties because of decay, natural hazard (earthquake and floods), human factor (theft, war, civil disorder, terrorism, neglect, and vandalism) is inevitable in the modern society (Teijgeler, 2006; Adamo, 2017, Vecco, 2017, and Vecco, 2018). Hence, This study aimed at providing information, shed light and enhances the reflection on the implication and impacts of neglect and flood weathering of heritage values of Dala Hill in line with the Sustainable Development Goals (SDGs) 8.9 and 11.4 that placed emphasizes on protection and safeguarding of heritage, and promote sustainable tourism that creates jobs and promotes local culture and products (Xiao, Mills, Guidi, Rodríguez-Gonzálvez, Barsanti, and González-Aguilera, 2018).

Development of a sustainability index of cultural heritage have been the focus of limited articles such as (Ribeiro, Lira, Piccolo, Pontual, 2012; Villase, Alonso, Magar, 2012; Mendes, Similä, 2012; and Nocca, 2017), whereas most authors placed attention on the relationship between sustainability and cultural heritage tourism (Landorf, 2009). The World Tourism Organization (WTO) have defined sustainable indicators as 'the set of measures that provide the necessary information to better understand the links between the impact of tourism on the cultural and natural setting in which this takes place (World Tourism Organization, 1996; and Nocca, 2017). WTO created guidelines for sustainable development of cultural tourism, these guidelines was grouped into three dimensions such as social, economic, and environmental (World Tourism Organization, 1996). Considering these dimensions, the potential of the subject matter "Dala Hill" is holistically examined. The present study aimed to explore the implications and effects of neglect on cultural heritage property "Dala Hill" in Kano metropolis, Nigeria, focusing on the targets of sustainable development goals (SDGs) 11 which states that cities should become 'inclusive, safe, resilient and sustainable', through 'inclusive and sustainable urbanization, planning and management' (Target 11.3) and efforts to protect and safeguard the world's Cultural and natural heritage' (Target 11.4). This target is to protect and safeguard cultural heritage.

\section{Theoretical Underpinning: Conservation theory (CT) and Dala Hill}

Considering the theme of the study, conservation theory was found important in explaining the subject matter. Conservation Theory is a socially constructed activity that interacts with and is governed by economic, political, spiritual, religious, social, 
and cultural dynamics in preserving the subject matter. This theory explains the changes in transformation process, from the materials of heritage objects to the values that cultural heritage holds for people through the three principles of materials-based, values-based, and peoples-based; taking cognizance of the external influences (social, political, technical, and economic). The theory turned away from the usual practice of preserving heritage, to a mechanism for the creation and re-creation of culture (Sully, 2013; Sully 2007). Going by the principles, materials-based principles explained the minimum treatment required to stabilize the subject matter, for instance, Dala hill as a heritage property is gradually deteriorating and weathering away through weather and climate action. This required social, political, technical, and economic intervention to aid its stability and restoration. The intervention should also be minimal to maintain, retain, and enhance the cultural significance of the hill. Lastly, this theory placed emphasis on the members of the host communities, in this regard the aspiration of the people residing in the community housing the subject matter were considered in the restoration process.

\section{Dala Hill: The History / Myth, and State of Art}

\section{History and Myth}

The Hausa Kingdom of Kano was based on an ancient settlement of Dala Hill surround by Dogon Nama, Bakin Ruwa, Adakawa, Yalwa, Kantudu, Kabuwaya, Gwammaja and Madigawa among other settlements. The residual hill is 534 meters (1,753 feet) high with a circumference of 788 meters, covering a land mass of 289,892 meters (Iliffe, 2007) as shown in Figure 1. There are steps on the hill which has 999 footsteps that aids ascending to the hill top (Adebayo, 2015). The site was the major source of iron ore, thus attracting skilled craftsmen to mine, smelt and forge iron as a basic economic and social activities to aid development during the seventh century (Nast, 2005). Mythically Dala hill served as abode for the deity of Tsumburbura and her priest Barbushe, who protected the people around the hill from their enemies.

\section{The State of the Art}

Dala hill, is a significant landmark and heritage tourism property in Kano, Nigeria. Despite its historical evolution and importance, it is in a state of fiascoes, facing both natural and human induced threats. Over the years, the hill has been affected by weathering (see figure 1 and 2), a situation that strengthen erosion to gradually wash away parts of the hill, reducing the surface area and creation of gullies around the hill. On the other hand, the hill has suffered serious encroachment from the locals in numerous ways, which includes the building of houses, dumping of refuse, open defecation on and around the hill, lack of management and maintenance leading to dilapidation of stairs, and the fence (see figure 1). Presently, the site serves as a 
desolate center that attracts out of school children, hoodlums, and criminals for moral and immoral activities; instead of its normal attraction components that generate economic activities in the locality.
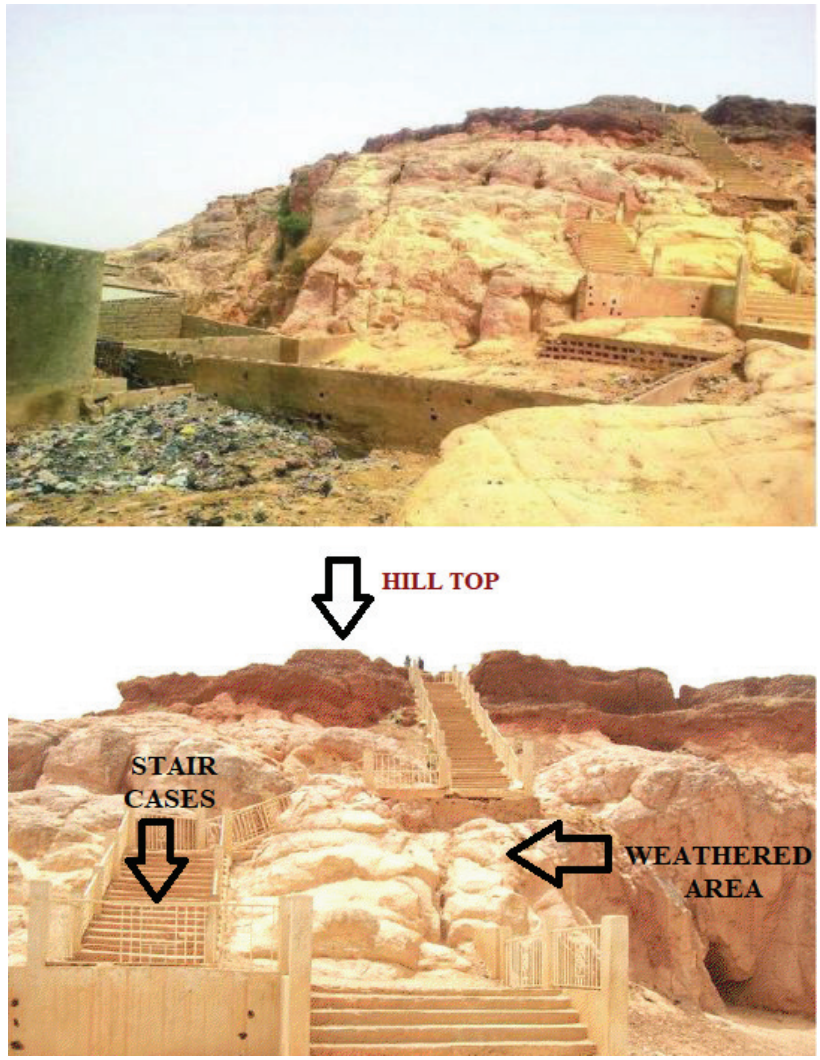

Figure 1. Dala Hill in its Present State

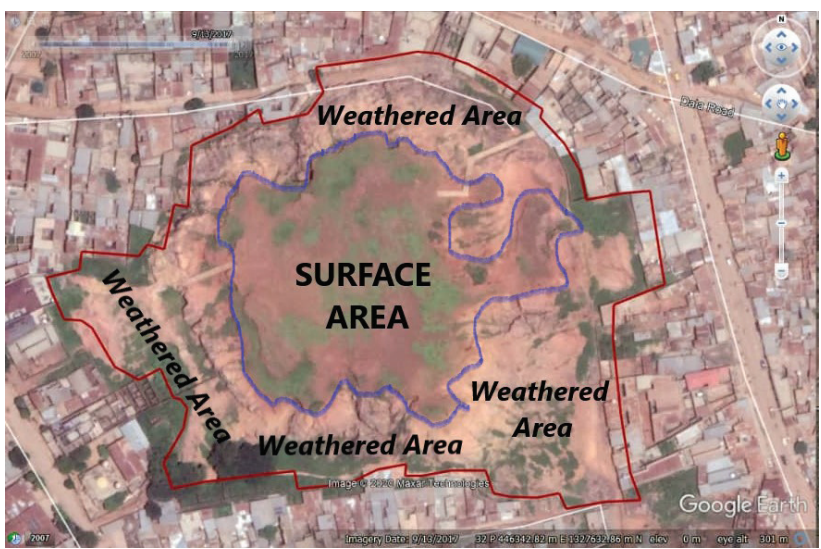

Figure 2. Aerial view of the subject matter and its environs 


\section{Research Methods}

The prospect and retrospective study is based on qualitative and quantitative research design. Considering the theoretical underpinning (Conservation theory), qualitative data was collected under the three principles of materials, values, and people, taking cognizance of the external influences such as economic, sociocultural, and environmental attributes. The survey period for data collection covers 3 months period from April to June 2021. Qualitative data was collected to valuate materials and values through detailed inventory of the site; the site was profiled by the authors during the survey period, global positioning system (GPS) was us to obtain the coordinates around the perimeter of the hill, delineating the boundaries, estimating the weathered areas, and determining the existing surface area. Direct observation was used in documenting the site in terms of pollution, (indiscriminate waste disposal, open defecation among others on the site); and profile the site's potential to accommodate hoodlums and criminal. Quantitative data was collected in the form of perceptual data from two categories of residents (The Elderly and Agile) within 300 meters vicinity to the site, this is because the resident within this radius would feel the impacts more than residents at a further distance (Dada, Odufuwa, Badiora, Agbabiaka, Ogunseye, \& Samuel, 2020).

This study targeted two categories of respondents (above 60years (Elderly) and Between 18 - 59years (Agile) and excluded residents below 18years (Minor) from the study. Due to the need to survey respondents who have deep knowledge and understanding about the happenings within and around the hill and importance of the hill. Therefore, forty-five elderly people were selected using snowballing sampling procedure, in this case the first respondent was contacted in the building adjacent to the site, in which forms the basis of referrer to subsequent respondents. Preliminary investigation revealed that there are 2620 buildings within the designated radius. Using systematic sampling, one of every tenth $\left(10^{\text {th }}\right)$ residential buildings were selected where any resident within the age categorization was selected. A total of 262 residents were surveyed. Data collected provided information on values and people's expectation and desire about the restoration of the past glory of Dala hill and to promote its potentials. Data collected was analyzed using pictorial analysis and Resident Perception Index (RPI) to rate the potential importance of the site.

\section{Analytical Methods}

A detailed inventory on the state of art of Dala hill were collected and documented. The perceptual data collected from residents was analyzed using the mean index. The residents were provided with a list of attributes (Economic, Sociocultural, and Environmental), identified in the literature, to measure their perception about the importance of Dala hill. The res pondents were instructed to score using a Likert 
scale rating $(5=$ strongly agree, $4=$ agree, $3=$ Neutral, $2=$ disagree and $1=$ strongly disagree) their level of agreement with each attribute. To compute the Resident Perception Index (RPI). The process is as follow:

(i). A weight value of 5,4,3,2 and 1 was attached respectively to each rating of strongly agree, agree, moderately agree, disagree, and strongly disagree.

(ii). Summation of the weight value (SWV) was computed. It is the addition of the product of the value attached to a rating and the respective number of residents to the rating.

(iii). The SWV was divided by the number of residents

This SWV is expressed mathematically as

$$
\mathrm{SWV}=\sum_{i=1}^{5} X_{i} Y_{i} \ldots \text { (i) }
$$

Where:

SWV = summation of weight value;

$\mathrm{X}_{\mathrm{i}}=$ number of residents to rating $\mathrm{i}$;

$Y_{i}=$ the weight assigned a value $(i=1,2,3,4,5)$.

The SWV, divided by the number of residents' gives the Resident Perception Index (RPI). It is expressed mathematically as:

$$
\mathrm{RPI}=\frac{S W V}{\sum_{i=1}^{5} i=X_{i}} \ldots \text {. (ii) }
$$

Where RPI is the Resident Perception Index, SWV and $P i$ are defined previously. The closer the RPI of a particular indicator to 5 the higher is assured of the importance attached to such indicator. Computation of Resident Perception Index (RPI) on importance of Dala Hill in Kano Metropolis as presented in Table 1

Column 1: Attributes (indicators)

Column 2: Number of individual respondents rating each of the indicators with 5 (Strongly agree)

Column 3: Number of individual respondents rating each of the indicators with 4 (Agree)

Column 4: Number of individual respondents rating each of the indicators with 3 (Undecided)

Column 5: Number of individual respondents rating each of the Indicators with 2 (Disagree) 
Column 6: Number of individual respondents rating each of the Indicators with 1 (Strongly disagree)

Column 7: Addition of product of individual respondents rating a particular indicator and their respective weight values. For instance, SWV for "Increase shopping opportunities" $=(282 \times 5)+(161 \times 4)+(21 \times 3)+(10 \times 2)+(9 \times 1)=2146$.

Column 8: Resident Perception Index (RPI) equals to the summation of weight value (SWV) divided by additional of individual respondents rating each indicator. For instance, $R P I$ for "Increase shopping opportunities" = 1077/(9+10+21+161+282) $=\frac{1077}{243}=3.12$

Column 9: Ranking of the indicators according to their rating.

\section{Findings and Result}

Going by the principle of the theoretical footings the result was presented in accordance with the three principles of materials, value, and people's perception. In order achieve the materials and value-based principles, the study undertook detailed profiling of the various elements within and adjoining to arrive at the existing situation of the site in terms of extent, height and size, and furtherance compute the resident perception of the importance associated to the subject site, presented as follows:

\section{Resident Perception of the Importance of Dala Hill}

\section{Economic Importance}

The study revealed that the residents has positive perception of 14 out of the 21 economic attributes and were ranked accordingly, they perceived that the potentials of the site include: Increase shopping opportunities (RPI $=4.43)$, Improves investment spending $(\mathrm{RPI}=4.16)$, Improves means livelihood $(\mathrm{RPI}=4.11)$, Increase employment opportunities (RPI =4.08), Improves local economy (PRI =4.14), Long term promotional benefit $(\mathrm{PRI}=3.90)$, Improves quality of life $(\mathrm{RPI}=3.90)$, Aid basic infrastructures rehabilitation $(\mathrm{RPI}=3.87)$, Increase in the price of land and housing $(\mathrm{RPI}=3.85)$, Increase in property taxes $(\mathrm{RPI}=3.76)$, Increase in average spending $(\mathrm{RPI}=3.72)$, Provides communal funding $(\mathrm{RPI}=3.76)$, Interruption of normal business $(\mathrm{RPI}=3.65)$, Earn foreign exchange $(\mathrm{RPI}=3.59)$, from $1^{\text {st }}$ to $14^{\text {th }}$ respectively. On the contrary, the residents believe that the potentials of the site would not Increase in cost of transportation, Leads to extraneous dependency, Increase in cost of living, Result in high leakage effect, Underutilized infrastructure, Inflation of goods and services, and Create scarcity of goods and services. The implication of the findings is that the economic benefits of the site as perceived by the residents will improve the standard of living of the people, elevate local economy and promote Small and medium scale enterprise (SME) among the locals (See Table 1). 
Table 1

Economic Importance

\begin{tabular}{lccccccccc}
\hline ATTRIBUTES & SD & $\mathbf{D}$ & $\mathbf{U D}$ & $\mathbf{A}$ & $\mathbf{S A}$ & $\mathbf{S W V}$ & $\mathbf{R P I}$ & $\mathbf{D E V}$ & $\mathbf{R}$ \\
\hline Increase shopping opportunities & $\mathbf{1}$ & $\mathbf{2}$ & $\mathbf{3}$ & $\mathbf{4}$ & $\mathbf{5}$ & & & & \\
Improves investment spending & 11 & 8 & 22 & 76 & 107 & 932 & 4.16 & 0.79 & $2^{\text {nd }}$ \\
Improves local economy & 15 & 17 & 8 & 66 & 119 & 932 & 4.14 & 0.77 & $5^{\text {th }}$ \\
Improves means livelihood & 12 & 23 & 11 & 61 & 117 & 920 & 4.11 & 0.74 & $3^{\text {rd }}$ \\
Increase employment opportunities & 9 & 20 & 21 & 68 & 107 & 919 & 4.08 & 0.71 & $4^{\text {th }}$ \\
Long term promotional benefit & 17 & 32 & 11 & 60 & 104 & 874 & 3.90 & 0.53 & $6^{\text {th }}$ \\
Improves quality of life & 10 & 28 & 26 & 70 & 89 & 869 & 3.90 & 0.53 & $7^{\text {th }}$ \\
Aid infrastructures rehabilitation & 11 & 31 & 22 & 74 & 87 & 870 & 3.87 & 0.50 & $8^{\text {th }}$ \\
Increase price of land and housing & 12 & 27 & 16 & 96 & 73 & 863 & 3.85 & 0.48 & $9^{\text {th }}$ \\
Increase in property taxes & 11 & 37 & 20 & 82 & 74 & 843 & 3.76 & 0.39 & $10^{\text {th }}$ \\
Provides communal funding & 18 & 26 & 23 & 78 & 76 & 831 & 3.76 & 0.39 & $12^{\text {th }}$ \\
Increase in average spending & 11 & 32 & 25 & 96 & 60 & 834 & 3.72 & 0.35 & $11^{\text {th }}$ \\
Interruption of normal business & 31 & 7 & 29 & 100 & 57 & 817 & 3.65 & 0.28 & $13^{\text {th }}$ \\
Earn foreign exchange & 17 & 39 & 20 & 89 & 58 & 801 & 3.59 & 0.22 & $14^{\text {th }}$ \\
Leads to extraneous dependency & 54 & 99 & 21 & 34 & 16 & 531 & 2.37 & -1.00 & $16^{\text {th }}$ \\
Increase in cost of living & 51 & 109 & 16 & 26 & 22 & 531 & 2.37 & -1.00 & $17^{\text {th }}$ \\
Increase in cost of transportation & 43 & 118 & 18 & 26 & 18 & 527 & 2.36 & -1.01 & $15^{\text {th }}$ \\
Result in high leakage effect & 58 & 95 & 28 & 25 & 19 & 527 & 2.34 & -1.03 & $18^{\text {th }}$ \\
Underutilized infrastructure & 55 & 106 & 26 & 26 & 11 & 504 & 2.25 & -1.12 & $19^{\text {th }}$ \\
Inflation of goods and services & 56 & 92 & 58 & 8 & 10 & 496 & 2.21 & -1.16 & $20^{\text {th }}$ \\
Create scarcity of goods and services & 107 & 60 & 14 & 23 & 16 & 441 & 2.00 & -1.37 & $21^{\text {st }}$ \\
TOTAL & $\mathbf{6 1 4}$ & $\mathbf{1 0 1 1}$ & $\mathbf{4 4 6}$ & $\mathbf{1 2 6 5}$ & $\mathbf{1 3 8 1}$ & $\mathbf{1 5 9 3 9}$ & $\mathbf{7 0 . 8 5} \mathbf{R P I}=\mathbf{3 . 3 7}$ &
\end{tabular}

Source: Author's computation 2021

\section{Sociocultural Importance}

The study revealed that the residents has positive perception of 16 out of the 27 Sociocultural importance attributes and were ranked accordingly, they perceived that the potentials of the site include: Foster support for festival celebration (RPI = 4.52), Showcase local culture (RPI $=4.42)$, Protection of local cultural identity (RPI = $4.34)$, Aid preservation of heritage properties (RPI $=4.28)$, Create entertainment and social support $(\mathrm{RPI}=4.23)$, Create opportunities for shopping $(\mathrm{RPI}=4.07)$, Create a sense of value and identity (RPI $=4.18)$, Increase interaction with locals (RPI = $4.12)$, Satisfying leisure needs (RPI $=4.11)$, Revitalization of arts $(\mathrm{RPI}=4.05)$, Diversify community economic activities (RPI $=4.03)$, Exchange of experiences and information $(\mathrm{RPI}=4.00)$, Create safer community $(\mathrm{RPI}=3.95)$, Commercialized local tradition $(\mathrm{RPI}=3.90)$, Fosters exchange of culture $(\mathrm{RPI}=3.83)$, and Change in community social structure $(\mathrm{RPI}=3.74)$, from $1^{\text {st }}$ to $16^{\text {th }}$ respectively. On the contrary, the residents believe that the potentials of the site would not increase prostitution, Lead to vandalism, Intensified pressure between locals and tourists, Change value system, Disrupt local activities, Create negative influence on the locals, Increase alcoholism, drug trafficking, and crime, Generate xenophobia, and lastly would not lead to Property damage (See Table 2). 
Table 2

Sociocultural Importance

\begin{tabular}{|c|c|c|c|c|c|c|c|c|c|}
\hline ATTRIBUTES & $\begin{array}{c}\text { SD } \\
1\end{array}$ & $\begin{array}{l}\text { D } \\
2\end{array}$ & $\begin{array}{c}\text { UD } \\
\mathbf{3}\end{array}$ & $\begin{array}{c}\text { A } \\
4\end{array}$ & $\begin{array}{c}\text { SA } \\
5\end{array}$ & SWV & RPI & DEV & $\mathbf{R}$ \\
\hline Foster support for festival celebration & 7 & 5 & 8 & 49 & 156 & 1017 & 4.52 & 1.25 & $1^{\text {st }}$ \\
\hline Showcase local culture & 8 & 11 & 7 & 51 & 147 & 990 & 4.42 & 1.15 & $2^{\text {nd }}$ \\
\hline Protection of local cultural identity & 5 & 6 & 8 & 94 & 111 & 972 & 4.34 & 1.07 & $3^{\text {rd }}$ \\
\hline Aid preservation of heritage properties & 6 & 16 & 5 & 80 & 117 & 958 & 4.28 & 1.01 & $4^{\text {th }}$ \\
\hline Create entertainment and social support & 6 & 13 & 12 & 86 & 107 & 947 & 4.23 & 0.96 & $5^{\text {th }}$ \\
\hline Create a sense of value and identity & 14 & 8 & 11 & 81 & 109 & 932 & 4.18 & 0.91 & $7^{\text {th }}$ \\
\hline Increase interaction with locals & 10 & 22 & 10 & 72 & 111 & 927 & 4.12 & 0.85 & $8^{\text {th }}$ \\
\hline Satisfying leisure needs & 18 & 15 & 11 & 61 & 120 & 925 & 4.11 & 0.84 & $9^{\text {th }}$ \\
\hline Create opportunities for shopping & 14 & 16 & 9 & 91 & 100 & 937 & 4.07 & 0.80 & $6^{\text {th }}$ \\
\hline Revitalization of arts & 10 & 20 & 26 & 60 & 108 & 908 & 4.05 & 0.78 & $10^{\text {th }}$ \\
\hline Diversify community economic activities & 19 & 10 & 13 & 87 & 96 & 906 & 4.03 & 0.76 & $11^{\text {th }}$ \\
\hline Exchange of experiences and information & 17 & 24 & 9 & 67 & 107 & 895 & 4.00 & 0.73 & $12^{\text {th }}$ \\
\hline Create safer community & 11 & 17 & 25 & 92 & 80 & 888 & 3.95 & 0.68 & $13^{\text {th }}$ \\
\hline Commercialized local tradition & 16 & 19 & 17 & 92 & 80 & 873 & 3.90 & 0.63 & $14^{\text {th }}$ \\
\hline Fosters exchange of culture & 17 & 27 & 14 & 86 & 80 & 857 & 3.83 & 0.56 & $15^{\text {th }}$ \\
\hline Change in community social structure & 21 & 32 & 10 & 80 & 80 & 835 & 3.74 & 0.47 & $16^{\text {th }}$ \\
\hline Create an increased in prostitution & 56 & 100 & 26 & 15 & 28 & 534 & 2.37 & -0.90 & $17^{\text {th }}$ \\
\hline Vandalism & 65 & 100 & 10 & 27 & 22 & 513 & 2.29 & -0.98 & $18^{\text {th }}$ \\
\hline Intensified pressure between participants & 89 & 57 & 26 & 30 & 22 & 511 & 2.28 & -0.99 & $19^{\text {th }}$ \\
\hline Change in value system & 58 & 99 & 31 & 21 & 15 & 508 & 2.27 & -1.00 & $20^{\text {th }}$ \\
\hline Disruption of local activities & 77 & 96 & 14 & 22 & 15 & 474 & 2.12 & -1.15 & $21^{\text {st }}$ \\
\hline Negative influence on the locals & 92 & 90 & 9 & 19 & 14 & 445 & 1.99 & -1.28 & $22^{\text {nd }}$ \\
\hline Increased alcoholism & 102 & 78 & 11 & 17 & 16 & 439 & 1.96 & -1.31 & $23^{\text {rd }}$ \\
\hline Increase drug trafficking & 100 & 70 & 31 & 14 & 9 & 434 & 1.94 & -1.33 & $24^{\text {th }}$ \\
\hline Increased crime & 96 & 90 & 26 & 7 & 5 & 407 & 1.82 & -1.45 & $25^{\text {th }}$ \\
\hline Generate xenophobia & 108 & 84 & 9 & 13 & 9 & 400 & 1.79 & -1.48 & $26^{\text {th }}$ \\
\hline Property damaged & 106 & 89 & 9 & 12 & 8 & 399 & 1.78 & -1.49 & $27^{\text {th }}$ \\
\hline TOTAL & 1148 & 1214 & 397 & 1426 & 1872 & 19831 & 88.36 & $\mathbf{R P I}=\mathbf{3}$ & \\
\hline
\end{tabular}

Source: Author's computation 2021

\section{Environmental Importance}

The findings from table 3 reveals that 9 out of the 18 environmental importance attributes are identified to be positive by the respondents, ranked from most agreed statements to least agreed statements, The table shows that the residents rates Conservation and restoration of heritage sites as the top most environmental importance of the Hill with RPI rating of 4.38, followed Increase considerable investment in infrastructure with RPI rating of 4.27, Creation of scenic beauty in the environment with RPI rating of 4.18, Creation of awareness on the need to protect the resources with RPI rating of 4.17,Improves park and recreation areas, RPI rating 4.13, Stimulate planning to improve amenities and business RPI rating 4.10, Potential aid in spread of tourism benefits RPI rating 4.07, Improvement in transport infrastructure RPI rating 4.03, Attract intervention protect natural environment RPI rating of 3.96 The residents also disagree with the fact that Dala hill Lead to overcrowding with RPI rating of 2.63, Causes an increases in noise pollution RPI rating of 2.50, create Traffic congestion RPI rating 2.42, Overstretch of resources RPI rating 2.38, leads to 
Loss of vegetation RPI rating 2.02, Create visual pollution RPI rating 1.98, Increase street littering RPI rating 1.93, causes Desert encroachments RPI rating 1.89 And the respondents rates the statement Causes an increase in air pollution with the lowest RPI rating of 1.85 . This proves that the hill will bring more environmental benefit than harm to the study area (See Table 3).

\section{Table 3}

Environmental Importance

\begin{tabular}{lccccccccc}
\hline ATTRIBUTES & SD & $\mathbf{D}$ & $\mathbf{U D}$ & $\mathbf{A}$ & $\mathbf{S A}$ & $\mathbf{S W V}$ & $\mathbf{R P I}$ & $\mathbf{D E V}$ & $\mathbf{R}$ \\
\hline Conservation of heritage sites & $\mathbf{1}$ & $\mathbf{2}$ & $\mathbf{3}$ & $\mathbf{4}$ & $\mathbf{5}$ & & & & \\
Increase investment in infrastructure & 2 & 5 & 8 & 99 & 109 & 977 & 4.38 & 1.22 & $1^{\text {st }}$ \\
Creation of scenic beauty & 5 & 11 & 9 & 92 & 107 & 957 & 4.27 & 1.11 & $2^{\text {nd }}$ \\
Creation of awareness on the need to & 9 & 21 & 8 & 70 & 117 & 940 & 4.18 & 1.02 & $3^{\text {rd }}$ \\
protect the resources & 6 & 10 & 26 & 80 & 102 & 934 & 4.17 & 1.01 & $4^{\text {th }}$ \\
Improves park and recreation & 12 & 16 & 10 & 80 & 106 & 924 & 4.13 & 0.97 & $5^{\text {th }}$ \\
Stimulate planning to improve amenities & 8 & 12 & 26 & 83 & 96 & 922 & 4.10 & 0.94 & $6^{\text {th }}$ \\
Aid in spread of tourism & 11 & 8 & 25 & 90 & 90 & 912 & 4.07 & 0.91 & $7^{\text {th }}$ \\
Improve transport infrastructure & 17 & 19 & 10 & 73 & 106 & 907 & 4.03 & 0.87 & $8^{\text {th }}$ \\
Attract intervention protect & 20 & 22 & 13 & 62 & 108 & 891 & 3.96 & 0.80 & $9^{\text {th }}$ \\
Lead to overcrowding & 51 & 75 & 24 & 41 & 28 & 577 & 2.63 & -0.53 & $10^{\text {th }}$ \\
Causes noise pollution & 56 & 86 & 19 & 37 & 25 & 558 & 2.50 & -0.66 & $11^{\text {th }}$ \\
Traffic congestion & 59 & 90 & 20 & 31 & 24 & 543 & 2.42 & -0.74 & $12^{\text {th }}$ \\
Overstretch of resources & 56 & 101 & 16 & 31 & 21 & 535 & 2.38 & -0.78 & $13^{\text {th }}$ \\
Loss of vegetation & 80 & 96 & 24 & 15 & 10 & 454 & 2.02 & -1.14 & 14 \\
Create visual pollution & 101 & 67 & 29 & 14 & 13 & 443 & 1.98 & -1.18 & $15^{\text {th }}$ \\
Increase street littering & 77 & 87 & 24 & 10 & 6 & 393 & 1.93 & -1.23 & $16^{\text {th }}$ \\
Desert encroachments & 92 & 90 & 26 & 10 & 7 & 425 & 1.89 & -1.27 & $17^{\text {th }}$ \\
Causes pollution & 96 & 87 & 24 & 10 & 6 & 412 & 1.85 & -1.31 & $18^{\text {th }}$ \\
TOTAL & 758 & 903 & 341 & 928 & 1081 & 12704 & 56.88 & $\mathbf{R P I = 3 . 1 6}$ \\
\hline Source Auth & & & & & & & &
\end{tabular}

Source: Author's computation 2021

The importance of Dala hill was established using indicators that were categorized into economic, sociocultural, and environmental dimensions. For this study, the rating scale is on a 5-point Likert's scale, therefore. The result of the computation of RPI for economic dimension is 3.38, sociocultural is 3.27, and environmental is 3.65. Consequently, we can say that the economic dimension accounted for the highest importance associated with Dala Hill, while that of sociocultural has moderate importance, and environmental dimensions has Low importance in the study area. Invariably, the combined index for the three dimensions is 3.28 , meaning that the overall importance associated with Dala hill moderate (See Figure 3). 


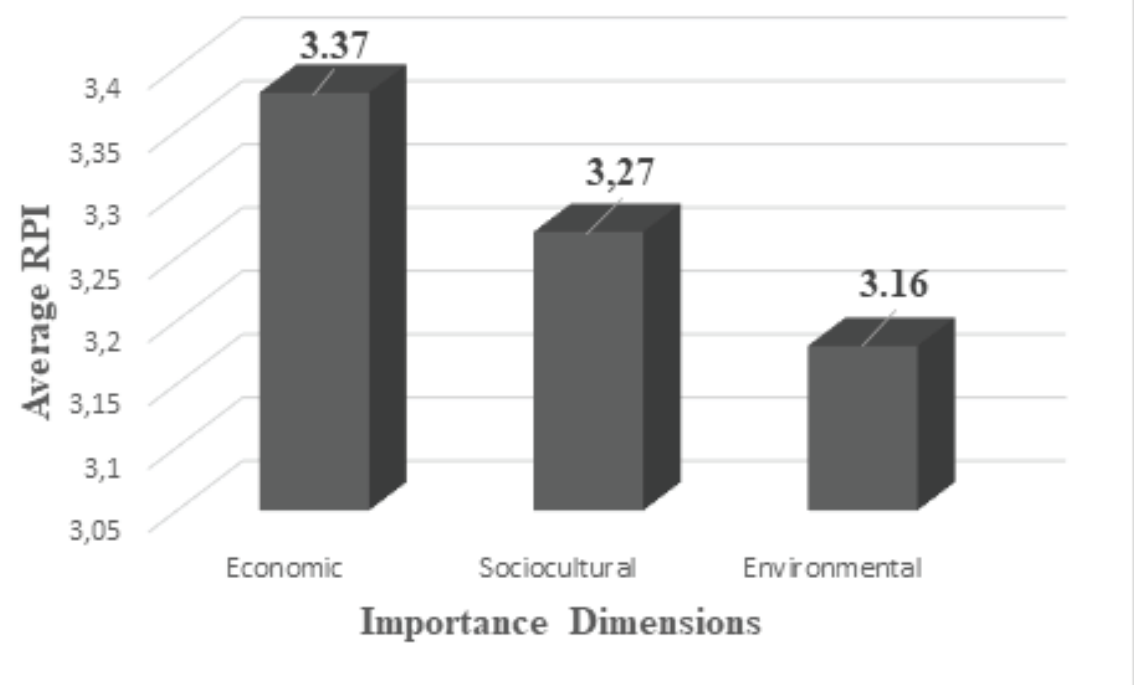

Figure 3. Combine Importance Associated with Dala

\section{Conclusion and Recommendation}

The study examined the tourism potential of Dala hill within the ancient Kano city. It identified complementary tourism potentials within the city wall and vicinity to Dala hill to include: thirteen (13) ancient city gates, Emir's Palace (Gidan Murufa), Historical Museum (Gidan makama), Kofar mata dying pits, Relics of ancient Kano walls, and ancient African famous market (Kurmi market). These are heritage properties surrounding the subject matter of the present study, which are worthy to review, as they form parts of external attraction components to the area. The site's major attraction component is its historical evolution. Despite the historical evolution attached to the hill, it has faced threat of decay and deterioration induced through weathering and human activities. Presently, the site is characterized with poor sanitary condition, open defecation, waste disposal, poor accessibility, and abode for hoodlums.

The residents presented the potentials of the site from three perspective. From the economic point of view, the respondents affirms that Dala hill has the potentials to Increase shopping opportunities, investment spending, means livelihood, employment opportunities, local economy, quality of life, price of land and housing, property taxes, average spending, communal funding, Interruption of normal business, Aid basic infrastructures rehabilitation and Earn foreign exchange, among others. From sociocultural perspective, the site has the capacity to Foster support for festival celebration, Create a sense of value and identity, Showcase local culture, Protect of 
local cultural identity, Aid documentation and preservation of heritage properties, Create entertainment and social support, Create a sense of value and identity, Increase interaction with locals. Satisfying leisure needs, Revitalization of arts, Exchange of experiences and information, Create safer community, Commercialized local tradition, and Fosters exchange of culture. The last perception of the resident is from environmental view point, which affirm that the has the potentials to Conservation and restoration of heritage sites, Increase considerable investment in infrastructure, Creation of scenic beauty in the environment, Creation of awareness on the need to protect the resources, Improves park and recreation, Attract intervention protect, and Stimulate planning to improve amenities, among others.

The implication of the study is that Dala Hill has enormous potentials that is beneficial to the visitors, members of the host communities, and the government as a tourism site Kano. Hence, the need for good planning and landscape design. In line with the findings, the following recommendations can be made:

Stakeholders should encourage the preservation of historic structures by providing necessary support, For instance, the government should create enabling environment for National Commission for Museums and Monuments in Nigeria (NCMM) to remove barriers and encourage private sector and community members to contribute to conserving heritage properties.

The Kano Emirate should engage with international bodies like United Nations on Educational Scientific and Cultural Organization (UNESCO) to promote the site to a world class standard. By attracting external aid in rehabilitating the heritage site to evolve its potentials and attraction components.

The concept of co-creation should be promoted through cooperate social responsibility and community participation by private sector and the locals to contribute their quota in protecting heritage properties

Adequate publicity on the potentials, attraction components, and significance of cultural heritage in local and international media.

Peer-review: Externally peer-reviewed.

Conflict of Interest: The authors have no conflict of interest to declare.

Grant Support: The authors declared that this study has received no financial support.

\section{References}

Adamo, S., \& Imperiale, F. (2017). Cultural Heritage and Challenges for Catastrophic Risk Management in Italy. Journal of Multidisciplinary Research, 9(1), 33-51.

Dada, O. T., Odufuwa, B. O., Badiora, A. I., Agbabiaka, H. I., Ogunseye, N. O., \& Samuel, O. 
S. (2021). Environmental hazard and health risks associated with slaughterhouses in Ibadan, Nigeria. Environmental Hazards, 20(2), 146-162. DOI: 10.1080/17477891.2020.1747382

Di Pietro, L., Mugion, R. G., Mattia, G., \& Renzi, M. F. (2015). Cultural heritage and consumer behavior: A survey on Italian cultural visitors. Journal of Cultural Heritage Management and Sustainable Development.160-79.

Iliffe, J. (2017). Africans: The history of a continent (Vol. 137). Cambridge University Press.

Landorf, C. (2009). A framework for sustainable heritage management: A study of UK industrial heritage sites. International Journal of Heritage Studies, 15(6), 494-510.

Nast, H. J. (2004). Concubines and power: Five hundred years in a northern Nigerian palace. University of Minnesota Press.

Nocca, F. (2017). The role of cultural heritage in sustainable development: Multidimensional indicators as decision-making tool. Sustainability, 9(10), 1882.

Mendes Zancheti, S., \& Simila, K. (2012). Measuring Heritage Conservation Performance; $6^{\text {th }}$ International Seminar on Urban Conservation; CECI \& ICCROM: Olinda, Brazil; Rome, Italy.

Ribeiro, C., Lira, C., F., Piccolo, R., Pontual, V., (2012), Conserving and identifying heritage: a

methodological contribution, in: S. Mendes Zancheti, K. Similä (Eds.), $6^{\text {th }}$ International Seminar on Urban Conservation; CECI \& ICCROM: Olinda, Brazil; Rome, Italy.

Sully, D. (2007). Decolonizing conservation: Caring for Maori meeting houses outside New Zealand (Vol. 3). Left Coast Press, Walnut Creek, CA.

Sully, D. (2013). Conservation theory and practice: Materials, values, and people in heritage conservation. The international handbooks of museum studies, 293-314.

Teijgeler, R. (2006). Preserving cultural heritage in times of conflict. Preservation management for libraries, archives, and museums. London: Facet Publishing, 133-165.

Vecco, M. (2010). A definition of cultural heritage: From the tangible to the intangible. Journal of cultural heritage, 11(3), 321-324.

Vecco, M., \& Srakar, A. (2018). The unbearable sustainability of cultural heritage: An attempt to create an index of cultural heritage sustainability in conflict and war regions. Journal of Cultural Heritage, 33, 293-302. https://doi.org/10.1016/j.culher.2018.06.009

Vecco, M., \& Imperiale, F. (2017). Cultural heritage: values and measures. What insurance value? Journal of Multidisciplinary Research (1947-2900), 9(1).

Alonso, V. I., \& Meurs, V. M. (2012). Assessing the performance of conservation activities. Measuring heritage conservation performance, $6^{\text {th }}$ International Seminar on Urban Conservation; CECI \& ICCROM: Olinda, Brazil; Rome, Italy, 1-14.

World Tourism Organization (1996), What Tourism Managers Need to Know: A practical Guide to the Development and Use of Indicators of Sustainable Tourism, WTO: Madrid.

World Tourism Organization (2004), Indicators of Sustainable Development for Tourism

Destinations. A Guidebook, World Tourism Organization: Madrid.

Xiao, W., Mills, J., Guidi, G., Rodríguez-Gonzálvez, P., Barsanti, S. G., \& González-Aguilera, D. (2018). Geoinformatics for the conservation and promotion of cultural heritage in support of the UN Sustainable Development Goals. ISPRS Journal of Photogrammetry and Remote Sensing, 142, 389-406. 
